\title{
VULNERABILIDAD Y PERIFERIA EN LAS INDIAS: CUMANÁ Y SU POBREZA ENDÉMICA ENTRE LOS SIGLOS XVII Y XVIII
}

\author{
Rogelio Altez \\ Universidad Central de Venezuela-Universidad de Sevilla \\ María N. Rodríguez ALARCón \\ Universidad Central de Venezuela
}

Fecha de recepción: enero 2015

Fecha de aceptación: mayo 2015

\section{LA HIJA DE LOS ALJÓFARES EXTENUADOS}

Muy atrás en el tiempo habían quedado los placeres perlíferos y el magnetismo de la sal. Ya hacia mediados del siglo XVII Cumaná y su región (en el actual oriente de Venezuela) eran un despojo difuminado de aquel atractivo impulsado por las perlas en las primeras décadas de la conquista. Las correrías holandesas tras las salinas de Araya, que tanto beneficio les produjera a los traficantes flamencos en los últimos años del siglo XVI, también se diluyeron tras largas décadas de escasez y abandono. Por los puertos de la zona no pasaba ni la Carrera de Indias, y sus habitantes miraban hacia el mar en espera de los comerciantes ilícitos, probablemente su única salvación en tiempos de tanta penuria.

Quizás los desastrosos intentos fundacionales entre 1514 y 1519 habrían servido de presagio a los siglos por venir. Todo ocurrió por el interés en las perlas, riqueza seductora cuyo valor despertó la codicia general y la apetencia de los más altos cargos en Europa. Su brillo circuló por los mercados de Amberes, Venecia, Lisboa y Sevilla, y hasta la propia Isabel de Valois lució un vestido con perlas encajadas procedentes de Cubagua, la isla que vivía del agua que tomaba del río de Cumaná y que vio crecer muy temprano a una ciudad con casas de piedra y edificios cuyo fulgor desapareció 
con la extinción de los yacimientos ${ }^{1}$. Pero los ostiales no representaban el único atractivo de la región en esas décadas iniciales; los indígenas, como mano de obra esclava, sirvieron de imán a los traficantes, cebados con los negocios que los propios aborígenes facilitaban al entregar a sus congéneres maniatados y destinados para el abuso de explotadores ${ }^{2}$.

El «ciclo de Cubagua», como lo llamó Pierre Chaunu3, envolvió al primer intento fundacional en el oriente de la Tierra Firme, y su breve y agitada duración no fue suficiente como para mantener el asentamiento. Entre los levantamientos de los naturales y las represalias de las armadas, tras apenas veinte años, todo fue arrasado, literalmente, por los indígenas, los esclavistas, los piratas, la expoliación, un terremoto y un huracán ${ }^{4}$. A comienzos de la década del 40 en el siglo XVI, ya Cubagua estaba abandonada, y el establecimiento en torno a la desembocadura del río que por entonces se llamaba Cumaná era un montón de cenizas. Los pocos que allí quedaron, de quienes nada se sabe acerca de su supervivencia, vinieron a ser rescatados por la fundación definitiva del lugar entre 1562 y 1569, y desde entonces jamás regresó el brillo de las perlas ni las disputas por aprovechar algo allí ${ }^{5}$. Sólo la sal, que parecía inagotable en la punta de Araya, vino a generar cierto atractivo por la región, aunque sus destellos nunca pudieron competir con los aljófares de los tiempos de la conquista.

1. Sobre los destinos comerciales de las perlas de Cubagua: OtтE, Enrique: Las perlas del Caribe: Nueva Cádiz de Cubagua, Caracas, Fundación John Boulton, 1977; y Rodríguez, José Ángel: «La geografía del poblamiento en la Venezuela hispánica», en Geo Venezuela, Volumen 1, La geografía histórica del poblamiento territorial venezolano, Edición de la Fundación Empresas Polar, Caracas, 2007, pp. 212253. Sobre el traje de Isabel de Valois: Landman, Neil H.; Mikkelsen, Paula M.; Bieler, Rudiger; y Bronson, Bennet: Pearls: A Natural History, New York, Harry N. Abrams-The American Museum of Natural History, 2001; y EmelinA, Martin Acosta: «La importancia de las perlas en el descubrimiento de América», Anuario de Estudios Atlánticos, N. 57 (2011), pp. 231-250. Hay imagen: «Isabella von Valois, Königin von Spanien», retrato elaborado por Alonso Sánchez Coello en 1560 que descansa en el Kunsthistorisches Museum Wien, bajo el Número de Inventario GG-31.

2. Mucho habría que decir sobre el asunto y muchas son las referencias documentales al respecto. Para una descripción contemporánea acerca de la participación de los indígenas en la trata de esclavos aborígenes, ver la narración de Benzoni, M. Girolamo: La Historia del Nuevo Mundo, Caracas, Academia Nacional de la Historia, 1967, original de 1541.

3. Chaunu, Pierre: Sevilla y América. Siglos XVI y XVII, Sevilla, Universidad de Sevilla, 1983.

4. El terremoto tuvo lugar el 1 de septiembre de 1530 y destruyó la fortaleza que se había construido en las bocas del río Cumaná, levantado allí para proteger el agua dulce con la que se abastecía a Cubagua. El huracán ocurrió en la navidad de 1541. Información sobre el terremoto en OтTЕ, Enrique: Las perlas del Caribe... op. cit., y en Grases, José; Altez, Rogelio, y Lugo, Miguel: Catálogo de Sismos Sentidos o Destructores, Venezuela 1530-1998, Caracas, Academia de Ciencias Físicas, Matemáticas y NaturalesFacultad de Ingeniería de la Universidad Central de Venezuela, 1999. Sobre el huracán: VILA, Pablo: «La destrucción de Nueva Cádiz. ¿Terremoto o huracán?», Boletín de la Academia Nacional de la Historia, XXXI, N. ${ }^{\circ} 123$, (1948), pp. 213-219. Descripción testimonial en: Castellanos, Juan de: Elegías de varones ilustres de Indias, Madrid, M. Rivadeneyra, 1857, p. 150.

5. Fue fundada por Diego Fernández de Serpa en 1569. El documento de fundación en: Archivo General de Indias (AGI), Santo Domingo, 71, Elección y nombramiento de la Justicia y Regimiento del Nuevo Pueblo de Córdoba. Sobre la fecha de fundación de Cumaná, véase: OJER, Pablo: «¿Cuándo se fundó la ciudad de Cumaná?», Boletín de la Academia Nacional de la Historia, XLVIII, N. o 191 (1965), pp. 424-430. 
Cumaná se levantó sobre los estertores de aquellos ensayos expoliadores. Como el resto de las regiones hoy venezolanas, no contó con minerales preciosos ni con otras riquezas de consideración ante los ojos de la metrópoli, lo que condujo su existencia a una vida anclada en la periferia. Sin perlas y sin poder explotar la mano de obra esclava, aquel territorio se vio sumido en la agrodependencia como las demás provincias que le rodeaban ${ }^{6}$. Su fundación, o más bien el rescate de aquellos pobladores abandonados a su suerte, fue el levantamiento de una ciudad que acabó siendo centinela de la sal por algunas décadas. Su mayor éxito fue el verse rodeada de fortalezas, casi todas ellas deficientes con excepción de la llamada «fuerza» o «castillo» de Araya, construida por el reconocido ingeniero italiano Juan Bautista Antonelli, cuya obra vino a ser una de las infraestructuras de mayor envergadura en las Indias. Prueba de la insolvencia de la región fue su escasa utilidad, alcanzando como destino la destrucción a manos del propio gobierno español en 1762, luego de haber sido abandonada por considerarla inoperante ${ }^{7}$. El resto de las fortificaciones jamás calzó los puntos de este monumento y

6. Creemos pertinente explicar qué entendemos por «agrodependencia», propuesta categorial que hemos utilizado en otras oportunidades (véase: Altez, Rogelio y Rodríguez Alarcón, María N.: «Plagas y coyunturas desastrosas en sociedades agrodependientes: Venezuela y la langosta a finales del Siglo XIX», en Peraldo Huertas, Giovanni, Editor: Plagas de langostas en América Latina. Una perspectiva multidisciplinaria, Costa Rica, Editorial Nueva Perspectiva-Universidad de Costa Rica, 2015, pp. 157-213). En tanto que «sociedad implantada», siguiendo a Germán Carrera Damas (véase del autor: «Introducción» a Formación Histórico Social de Venezuela, CARrera Damas, Germán, Coordinador, Caracas, Ediciones de la Biblioteca de la Universidad Central de Venezuela, 1981, p. 10), las condiciones de producción y estrategias de supervivencia desplegadas por la sociedad colonial en general no son, en sí mismas, originarias, sino el resultado de diversas mixturas y procesos heterogéneos, pero siempre conducentes al desarrollo de modos de producción enfocados en el beneficio de la metrópoli, en primera instancia, y de las élites locales o regionales, en consecuencia. En los lugares carentes de minerales preciosos, especialmente, la economía de subsistencia basada en la recolección, la siembra y la cría, no fue una opción, sino una salida, un medio de supervivencia, y más tarde un medio de enriquecimiento particular y de reproducción de desigualdades y desequilibrios. Tal dependencia de las condiciones agrícolas, además, no redundó en una adaptación que se correspondiera con su medio ambiente. De allí que afirmamos que, en tanto que sociedad implantada, no fue por naturaleza una cultura agrícola, como podría calificar la antropología a ciertas sociedades cuya existencia se ha reproducido desde modos de vida originalmente conformados con esos recursos. Por ello la señalamos como agrodependiente, y no como una sociedad agrícola, diferencia que no es un juego de palabras. M. DobrowolsKa (citado por Kula, Witold: Problemas y métodos de la historia económica, Madrid, Ediciones Península, 1977, p. 521) dijo lo siguiente: «la relación entre la sociedad y el medio geográfico no es una relación constante basada en unas leyes inmutables y duraderas sino una relación variable, la cual se refleja en la transformación incesante de las dependencias». Creemos que en el caso de las regiones hoy venezolanas, la dependencia agrícola, que sintetizamos como agrodependencia, fue el rostro insoslayable de una economía de subsistencia no siempre exitosa, desplegada especialmente en los primeros dos siglos de existencia colonial.

7. Sobre la fortaleza hay información y estudios documentados en: GASPARINI, Graziano: Arquitectura colonial en Venezuela, Caracas, Ediciones Armitano, 1965; CALderón QuiJano, José Antonio: Las fortificaciones españolas en América y Filipinas, Madrid, MAPFre, 1996; RAmos PÉRez, Demetrio: «El esfuerzo defensivo. Las guarniciones y las fortificaciones», Historia General de España y América, Tomo IX-I, «América en el siglo XVII. Los problemas generales», Madrid, Ediciones Rialp, 1985. Sobre su proceso de deterioro progresivo y final hay información documental; véase: AGI, Santo Domingo, 584, Relación de don Juan de Padilla Guardiola, Cumaná, 9 de enero de 1682; AGI, Caracas, 469, Los oficiales Reales 
su papel nunca fue determinante, más allá de los gastos que ocasionaban o de haberse utilizado como residencia de los gobernadores, tal como sucedió con el fuerte de Santa María de la Cabeza ${ }^{8}$.

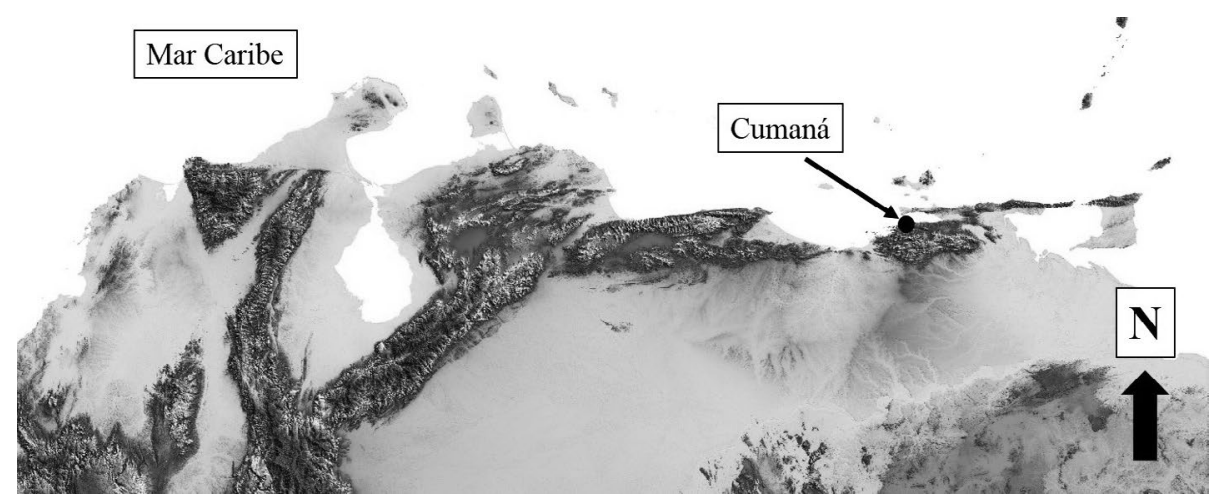

Figura 1. Ubicación relativa de Cumaná en la zona Norte del continente suramericano. Elaboración propia9.

La agrodependencia tampoco fue eficiente, sino deficitaria, como la propia materialidad de Cumaná. Fue un sitio expuesto y sometido a las «plagas elementales», a decir de Witold Kula ${ }^{10}$, susceptible de verse azotado por las propias condiciones ambientales y fenoménicas características de la región, pero ante las cuales no se desarrollaron recursos eficaces de adaptación en ningún momento. Al igual que las «ciudades frágiles» que observó Alain Musset, Cumaná enfrentó a la naturaleza como si se tratase de un castigo, una constricción, un padecimiento: «la naturaleza se valía de argumentos más brutales para lograr sus fines», asegura el investigador francés con relación a otros ejemplos por el estilo ${ }^{11}$. En su condición de ciudad «pre-

de Cumaná, y Castillos de San Antonio y Fuerza de la Punta de Araya. Informe, 6 de septiembre de 1685; AGI, Santo Domingo, 622, Fortificaciones de Cumaná y Margarita, 1622-1714; sobre la demolición final: Servicio Histórico Militar, 5-3-10-11, N. ${ }^{\circ}$ 6978, Relación del Castillo de Araya y su salina, con reflexiones sobre el proyecto de reparación, Francisco de Hurtado y Pino, Cumaná, 6 de noviembre de 1777. Al final del documento se indica que había sido demolido en 1762 . Sobre la vida y obras de los Antonelli, padre e hijo, y de Cristóbal de Roda, también ingeniero y primo de Juan Bautista, véase: www. provincia.fc.it/cultura/antonelli/esp/storiaattivita/GiovanniBattistaElMozoAntonelli.html

8. Martínez-MendozA, Jerónimo: «Nuestras fortificaciones coloniales», El Farol, N. ${ }^{\circ}$ 192, XXII, (1961), pp. 43-54. También: GaSParini, Graziano: Las fortificaciones del período hispánico en Venezuela, Caracas, Ediciones Armitano, 1985.

9. Mapa base elaborado por Jarvis, Andy; Reuter, Isaac; Nelson, Andrew; y Guevara, Edward, Hole-filled SRTM (Shuttle Radar Topographic Mission - CIAT V4) for the globe Version 4, CGIAR-CSI SRTM 90m Database, 2008, disponible en: http://srtm.csi.cgiar.org/SELECTION/inputCoord.asp

10. Kula, Witold: Problemas y métodos de la historia económica, op . cit.

11. Musset, Alain, Ciudades nómadas del Nuevo Mundo, México, Fondo de Cultura Económica, 2011, p. 213. 
industrial», como lo indicó Kula al referirse a las sociedades dependientes de la agricultura, Cumaná enseñó una subordinación a la recolección, la siembra y la cría que se vio supeditada a las condiciones materiales que se correspondían con la periferia, esa «posición marginal» dentro de las Indias a la que se refirió Chaunu. Esto, desde luego, hizo de sus habitantes una sociedad frágil y pobre, expuesta a todas las amenazas.

Al igual que en la Provincia de Caracas o en la de Mérida, Cumaná vivió largos años sin moneda y en su caso utilizó al maíz como sustituto, aunque en varias oportunidades ni siquiera este producto autóctono resolvió sus periodos de quiebra. Las construcciones fortificadas, cuya solidez debería ser proporcional a sus funciones defensivas, demostraron fragilidad y en algunos casos una corta duración. La vulnerabilidad general de la ciudad y de la región que encabezaba se vio expresada regularmente en casi todos sus flancos: en lo económico, en lo material, en la organización, y especialmente en su relación con el medio ambiente en el que se hallaba enclavada.

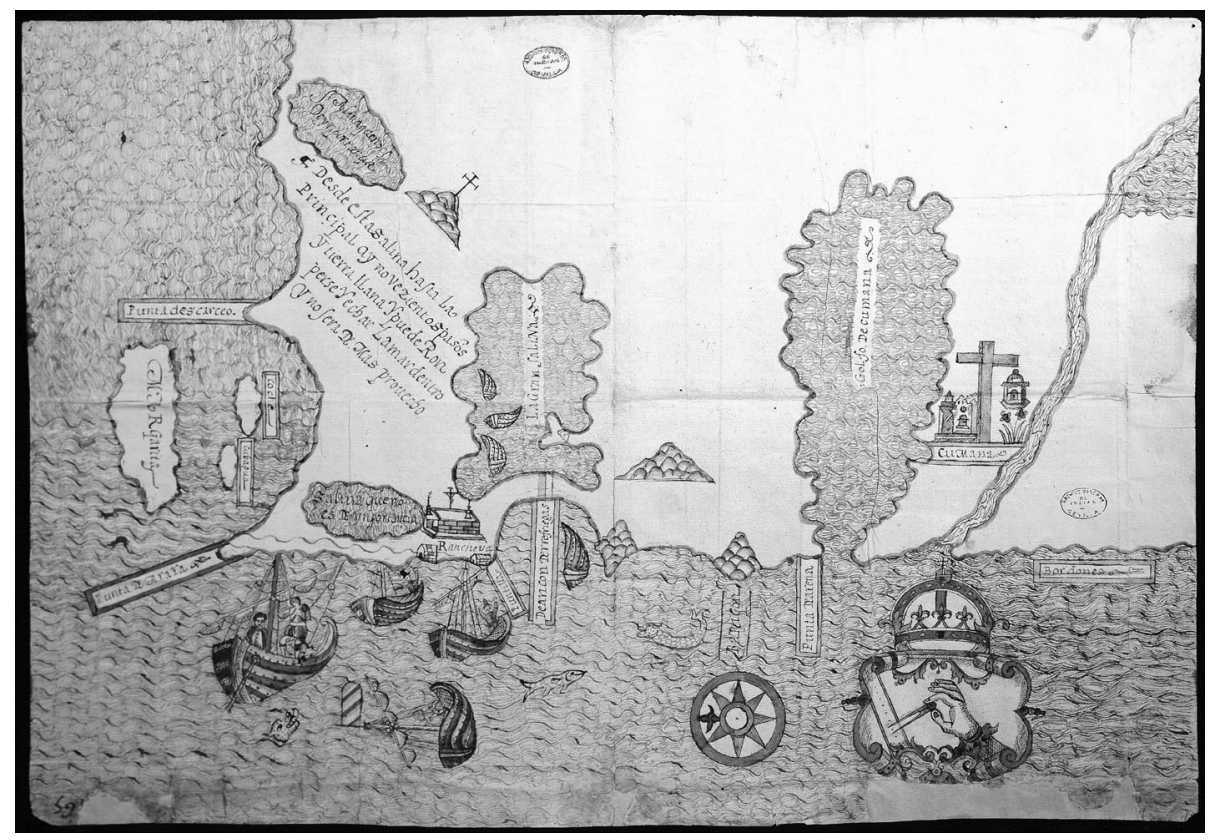

Figura 2. Planta de las salinas de Araya y costa hasta Cumaná, c. $1600^{12}$.

12. AGI-Mapas y Planos, Venezuela, 9; tomado de El Continente de Papel. Venezuela en el Archivo de Indias, Caracas, Ediciones Fundación Neumann, 1984, p. 27. 


\section{EL RÍO, LA SAL Y LA DEFENSA DE LA CIUDAD}

A pesar de la común insistencia proveniente de la historia más tradicional, Cumaná no fue fundada entre 1514 y 1519, sino unas décadas después, como lo comentamos anteriormente $^{13}$. Las construcciones de dominicos y franciscanos, devastadas por los levantamientos indígenas y finalmente abandonadas, ni siquiera fueron la base de la fundación que posteriormente se hiciera en 1562, ni la que acabó siendo su establecimiento definitivo y sin solución de continuidad hasta el presente, desde $1569^{14}$. Este hiato entre aquellos intentos y su consolidación ya indica que el caserío que allí se levantó no podría ser una ciudad próspera.

Treinta años después de aquel establecimiento las relaciones y descripciones sobre el lugar daban cuenta de su pobreza. Una iglesia sin campanas y unas cuantas casas de paja riesgosas de incendios pintaban su horizonte urbano. Los despachos de hacienda acabaron derrumbándose por sí mismos hacia 1611, por ejemplo, mientras que en esos años la iglesia continuaba siendo pajiza y de bahareque, deshaciéndose sus paredes por falta de consistencia y lloviéndose regularmente por las averías en el techo ${ }^{15}$. Asentada a orillas del río, y especialmente enclavada al pie de una pequeña elevación que limitó su expansión, Cumaná se hallaba a merced del cauce con cada crecida. Se propusieron mudarla en 1604, y aunque el cabildo aprobó la decisión, esto nunca se llevó a cabo. Los vecinos damnificados por el derrumbe de sus viviendas con las avenidas, «vivían de prestado» en otras casas por la carencia de recursos ${ }^{16}$. También los contagios de viruelas habían mermado la población y profundizado su miseria; por ello hacia 1602 decían que la ciudad «está muy pobre y necesitada» ${ }^{17}$.

Pero fue la sal de Araya lo que eventualmente revitalizó la región, con especial énfasis en el contexto de finales del siglo XVI y comienzos del XVII, cuando los holandeses se abastecían allí con gran libertad, y muchas veces en connivencia con las autoridades cumanesas ${ }^{18}$. No obstante, fue uno de sus gobernadores, Diego Suárez

13. OJER, Pablo: «¿Cuándo se fundó la ciudad de Cumaná?», op. cit.

14. Acerca de los detalles de este proceso descrito sobre fuentes documentales, ver: OJER, Pablo: La formación del oriente venezolano, I, Creación de las gobernaciones, Caracas, Instituto de Investigaciones Históricas, Universidad Católica Andrés Bello, 1966; y Castillo Hidalgo, Ricardo I., Asentamiento español y articulación interétnica en Cumaná (1520-1620), Caracas, Academia Nacional de la Historia, 2005.

15. AGI, Santo Domingo 190, La ciudad de Cumaná al rey, Cumaná, 15 de febrero de 1613.

16. AGI, Santo Domingo, 187, R. 3, N. 14, Diego Suárez de Amaya al rey sobre la pesca de perlas, vela de la salina, mudanza de la ciudad de Cumaná y vacante de Obispado de Venezuela, Cumaná, 22 de mayo de 1604.

17. AGI, Santo Domingo 190, La Ciudad de Cumaná sobre que se le haga merced de ciertas cosas contenidas de su relación, Cumaná, 6 de marzo de 1602.

18. El trato de los holandeses con la región debido a la explotación de la salina de Araya aparece documentado desde esos años. El gobernador Diego Suárez de Amaya informaba que los holandeses estaban «como si estuvieran en sus tierras», dando cuenta de la comodidad en la que se hallaban con el tráfico de la sal, y decía que en ello había hasta «mil hombres en la carga» (AGI, Santo Domingo, 187, R. 3, N. 3, Cumaná, 2 de julio de 1600). Usaban «zuecos de palo», para que no se les consumiesen los zapatos de cuero, y tenían allí «cuatro o cinco caminos entablados, por donde llevan la sal con carretones», así 
de Amaya, quien promovió la apertura de un canal en el río que pasaba por la ciudad para que ofreciese una salida alternativa, más próxima a Araya, que facilitara el acceso rápido a su defensa por medio de naves pequeñas y ligeras. Ya en 1601, Suárez de Amaya había tenido enfrentamientos con los flamencos, por lo cual solicitaba ayuda económica y militar al rey ${ }^{19}$.

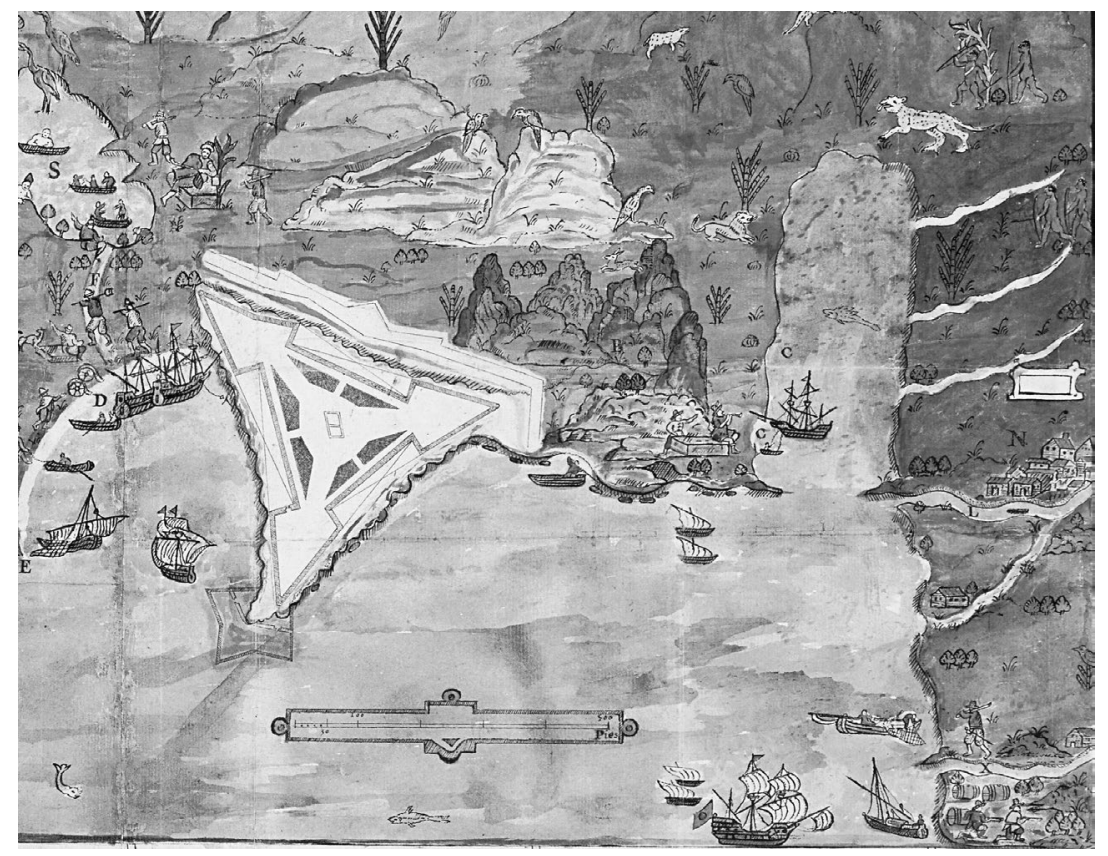

Figura 3. Detalle del plano Planta irregular para el sitio sobre el surgidero de Ancón de refriegas en la salina de Araya, hecha por el capitán don Andrés Rodríguez de Villegas, gobernador de esta isla Margarita por el Rey, nuestro señor, $1623^{20}$.

como muelles en la playa para facilitar el trasiego a sus navíos (Biblioteca Nacional, Madrid, Manuscrito 2347, Relación de la gran salina de Araya, esta dicha salina en diez grados de altura entre el Trópico de Cancro [sic] y la Equinoccial, por Bautista Antonelli, ff. 90r-95v, sin fecha, c. 1604). Cuando el gobernador Diego de Arroyo Daza les enfrentó en 1621 halló que tenían un fuerte de madera en el lugar (AGI, Indiferente, 111, N. 86, Memorial de Servicios del Capitán don Diego de Arroyo Daza, Memorial de Servicios del Capitán don Diego de Arroyo Daza, Gobernador y Capitán General que fue de la Provincia de Cumaná, donde caen las Salinas de Araya, Impreso sin pie de imprenta, probablemente de 1629).

19. AGI, Santo Domingo, 187. Véanse los documentos fechados en Cumaná a 13 de febrero y 27 de mayo de 1601; todo el legajo ofrece información al respecto, especialmente entre los documentos N. ${ }^{\circ} 6$ a 25. También en AGI-Mapas y Planos (MP), Venezuela, 10, donde puede verse el mapa enviado por Suárez de Amaya proponiendo el canal, con fecha 13 de febrero de 1601. Sobre los enfrentamientos con los flamencos: AGI, Santo Domingo, 187, R. 3, N. 7, Diego Suárez de Amaya al rey, Cumaná, 13 de febrero de 1601.

20. AGI-Mapas y Planos, Venezuela, 10, 15 de mayo de 1623, tomado de El Continente de Papel, op. cit., p. 29. 
Mientras el gobernador confrontaba a los comerciantes ilícitos, los pobladores cultivaban sus negocios con los extranjeros. Sacaban provecho del tabaco sembrado en otras localidades cercanas y accedían a intercambios con navíos escoceses, franceses y holandeses. Esto sucedía en torno a Cumanagoto, por ejemplo, poblado levantado por el mismo fundador de Cumaná, Fernández de Serpa, sobre el que se solicitaba su «extinción» por considerársele inútil y sin «oro ni plata ni pesca de perlas» ${ }^{21}$. Tal diferencia en la percepción de valores es indicador de aquel contexto: por un lado, el tabaco resultaba un recurso alternativo de intercambio y supervivencia para indígenas y pobladores; por el otro, los minerales y los placeres perlíferos continuaban siendo estimados como objetos preciosos que otorgaban sentido a la ocupación de la región.

Por la defensa de la sal se proyectó el desvío del río y por ello se abrió un canal, en una fecha aún no precisada luego de lo propuesto por Suárez de Amaya en 1601, que comunicaba a Cumaná con el llamado Puerto de Ostias. Se cavaron trincheras defensivas en la entrada de la ciudad y se podó el monte de las márgenes que podrían permitir escondites al enemigo. También la custodia de Araya habría estimulado un conjunto de decisiones e indecisiones que, insoslayablemente, determinarían el destino de la región y sus vecinos.

Las largas discusiones en torno a la creación de una flota patrullera que finalmente será establecida con el nombre de Armada de Barlovento hacia 1635, perjudicaron severamente a la zona con su dilación, pues desde que Suárez de Amaya solicitara ayuda militar hasta la creación de esta escuadra, pasaron más de tres décadas. El establecimiento de la flota, cargada a las cajas de Caracas entre otras, vino a sellar una medida que, por defecto, aisló a Cumaná, pues para evitar riesgos ante la amenaza de los enemigos extranjeros, la Carrera de Indias dejaría de pasar a partir de 1630, y definitivamente quedará apartada de aquellos puertos desde $1645^{22}$. La Armada de Barlovento fue, para la región entera, un cerco hacia fuera y hacia dentro.

También la custodia de la Península de Araya condujo a otra decisión de peso para Cumaná: la construcción de su fortaleza, obra que tardó más de veinte años en ejecutarse, aunque en realidad su culminación se indica hasta cuatro décadas después de su inicio. Comenzada entre 1623 y 1625 por Antonelli, será rematada en los años '60 por el ingeniero Bartolomé Pernelete ${ }^{23}$. La obra cumplió su cometido, pues finalmente los holandeses se retiraron de la zona. Sin embargo, tal repliegue representó un aislamiento mayor para los habitantes, que ahora ya no tenían la alternativa de intercambio ofrecida por los navíos flamencos.

Esta no fue la única fortificación estimulada por la defensa de la sal. Sí fue la más sólida, desde luego, como lo demuestra su inversión. El mismo ingeniero Pernelete levantó una batería que llamaron de Santa Catalina en la desembocadura del canal

21. AGI, Santo Domingo, 584, Anónimo al rey, Valladolid, 3 de marzo de 1606.

22. Sobre la flota, Torres Ramírez, Bibiano: La Armada de Barlovento, Sevilla, Escuela de Estudios Hispano-Americanos, 1981; sobre el cese del arribo de la Carrera de Indias, Chaunu, P.: Sevilla y América..., op. cit.

23. GASPARINI, G.: La Arquitectura colonial, op. cit., p. 305. 
abierto por idea de Suárez de Amaya. La obra, de estacas y barro, fue finalizada en 1666. Hacia 1674 ya se había caído por sí misma. Una década más tarde fue abandonada $^{24}$.

Pocos años antes de esa construcción, en 1659, se produjo un ataque de piratas ingleses, lo que estimuló el levantamiento de un fuerte dentro de la ciudad al que se llamó San Antonio de la Eminencia, culminado en 1669. Un par de años después se terminaba otra fortificación para resguardo de Cumaná, denominada Santa María de la Cabeza, la que sirvió de residencia de los gobernadores. En 1704 se construyó el Reducto de La Candelaria, convirtiendo a la ciudad en un recinto de tres defensas fuertes ${ }^{25}$.

Entre el resguardo de la sal y la protección ante las incursiones de piratas, Cumaná tardó un siglo en atrincherarse. No fue eficaz en estos propósitos, y tampoco lo fue en su intento de defenderse del río. La temprana preocupación de Suárez de Amaya por mudar la ciudad y escudarse de las avenidas poco efecto tuvo. La construcción del canal quizás apuntó a aliviar los embates del cauce, pero la proximidad de la ciudad a la corriente le hizo históricamente vulnerable a sus arremetidas. Hay que sumar a la apertura del canal la decisión de secar el cauce original, como medida que perseguía atenuar la amenaza, aunque la regularidad de las incursiones del río sobre la ciudad hizo de esta obra una discusión centenaria a la que se volvería una y otra vez en adelante.

Las construcciones fortificadas y la convivencia con el río se pondrían a prueba en varias oportunidades entre las últimas décadas del siglo XVII y los primeros años del siglo XVIII. Todo habría de comprobar, desde luego, que la pobreza sobre la que se fundó Cumaná fue determinante en las condiciones materiales de su existencia, tanto en la ineficacia de sus defensas como en las vulnerabilidades generales que acompañaron la cotidianidad de sus habitantes.

24. Sobre su construcción: AGI, Santo Domingo, 620, Carta del gobernador don Juan Bravo de Acuña en la que expone las incidencias de los piratas ingleses, desalojamiento de los holandeses en la isla del Tabaco, propósito de atacar Trinidad para dominar aquella zona, robo reiterado de Cumaná y obras de la fortaleza, Cumaná, 7 de mayo de 1666. Sobre su deterioro: AGI, Santo Domingo, 187, Juan Bentura de Palacio Rada al rey, Cumaná 10 de marzo de 1674. Sobre su abandono: AGI, Santo Domingo, 585, Gaspar Mateo de Acosta al rey, Cumaná, 8 de abril de 1687.

25. Del ataque de los ingleses, véase: AGI, Santo Domingo, 622, Juan de Ybarreta Ladrón de Guevara al rey, Cumaná, 13 de junio de 1659. También: Relaciones históricas de las Misiones de Padres Capuchinos de Venezuela. Siglos XVII y XVIII, Madrid, Librería General de Victoriano Suárez, 1928, p. 28. Sobre el resto de las fortificaciones, San Antonio de la Eminencia, Santa María de la Cabeza y el Reducto de La Candelaria, véase: OJER, Pablo: «Estudio Preliminar y Edición Crítica» al libro de CAulíN, Fray Antonio: Historia de la Nueva Andalucía, Caracas, Academia Nacional de la Historia, 1966; GASPARINI, G.: Las fortificaciones del período hispánico..., op. cit.; y MARTíneZ-MendozA, J.: «Nuestras fortificaciones coloniales», op. cit. De las muchas imágenes que hay sobre estas fortificaciones, señalamos las siguientes: AGI-MP, Venezuela, 60, Planta del castillo de Santa María de la Cabeza en Cumaná, 25 de febrero de 1682; AGI-MP, Venezuela, 61, Planta del fuerte de San Antonio en Cumaná, 25 de febrero de 1682; AGI-MP, Venezuela, 76, Plano de Cumaná y sus fortificaciones, 7 de diciembre de 1725; AGI-MP, Venezuela, 42, Planta del fuerte de Santa Catalina en la boca del río de Cumaná, 1666. 


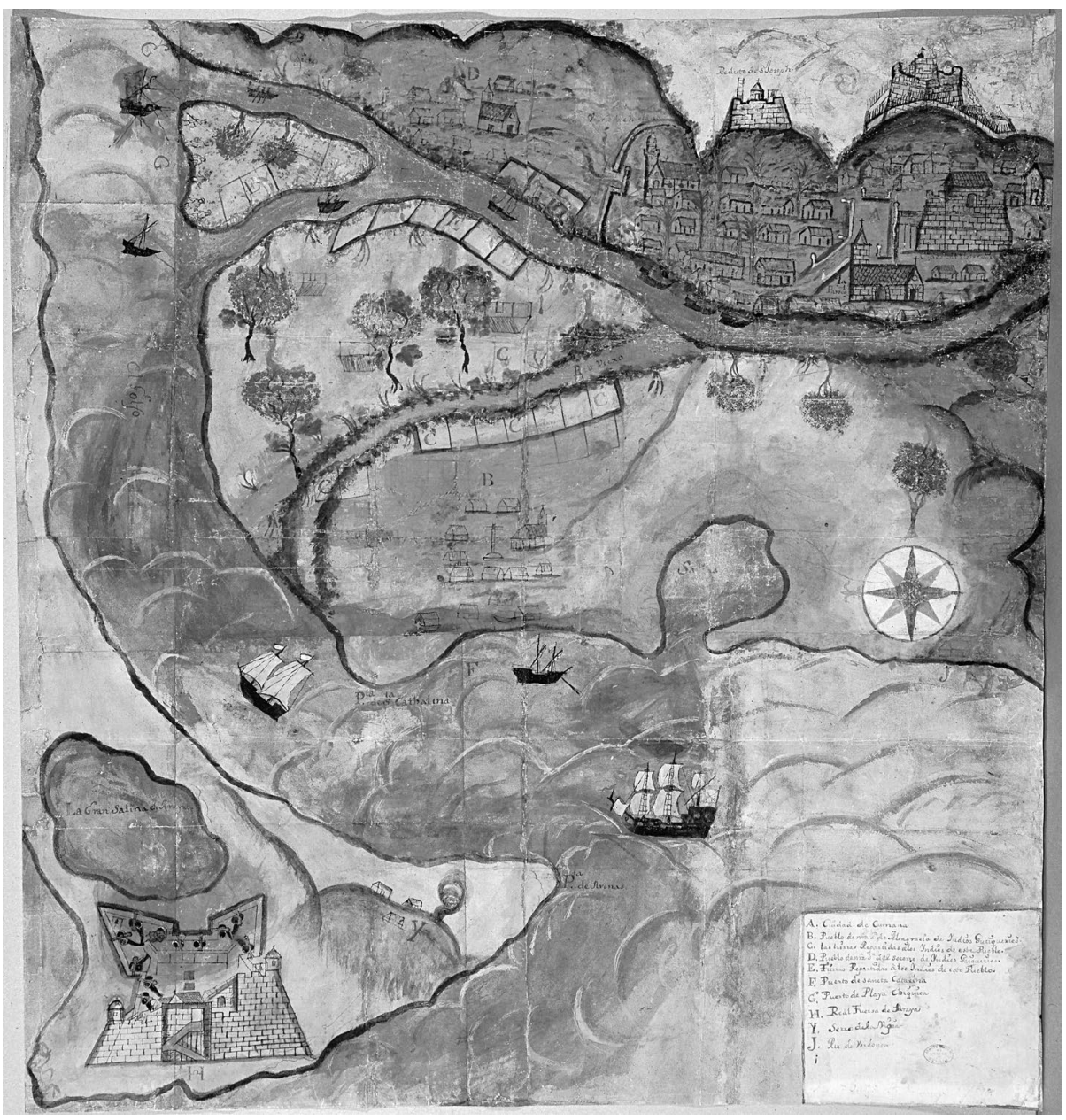

Figura 4. Plano del pueblo de Nuestra Señora de Altagracia y del reparto de tierras a los indios del mismo, con vista de Cumaná y de la fortaleza de Araya, $1704^{26}$.

\section{VULNERABLES A TODO}

Nada en la historia fundacional de Cumaná contribuyó con una base sólida sobre la cual desarrollarse. Con las perlas de sus islas agotadas y la migración de los comerciantes, la ciudad se levantó a hombros de unos cuantos habitantes sin recursos. En adelante, una vida de penurias les esperaba. No pudieron ser los aprovechadores de

26. AGI-Mapas y Planos, Venezuela, 72, tomado de El Continente de Papel, op. cit., p. 41. 
la sal, a pesar de la riqueza de aquel producto cuyo uso fue perentorio en el mundo occidental hasta el invento de la refrigeración. Tampoco pudieron competir explotando el tabaco de sus tierras, estancado por la Corona desde comienzos del siglo XVII en detrimento de todas aquellas provincias, salvo Barinas, favorecida por la calidad de su hoja. Estaban lejos de ser una urbe apacible al convivir con un río que no vino a domesticarse sino en el siglo XX. Apenas sobrevivían del intercambio con los extranjeros, que ya poco interesados estaban en la región después de verse expulsados por la vigilia de Araya. Más atractivo resultaba el lugar para los piratas, que se atrevieron hasta el incendio de la ciudad en 1659. Y a todo esto habría que sumar la regularidad de los temblores, pues Cumaná se haya asentada sobre la zona de mayor actividad sísmica de la actual Venezuela, algo que demostró con su historia desde sus primeros intentos fundacionales.

El sismo y el tsunami del 1 de septiembre de 1530 no pudieron dejar memoria en una ciudad que no existía entonces y que no dejó herederos después de esos años. Quizás por ello cuando en una fecha imprecisa de 1629 les sorprendiese otro terremoto la ciudad se hallaba desapercibida de tal amenaza. Con todo, no eran los temblores los que en aquellos años les hacían temer por una desgracia, sino los ingleses. De los daños sufridos con el fenómeno telúrico también tardaron años en recuperarse, aunque tal afección formaba parte de un conjunto mayor de miserias que les aquejaban como para solicitar ayuda periódicamente a la metrópoli ${ }^{27}$.

Este sismo, olvidado en el tiempo y perdido entre papeles, fue uno más de los escollos de aquel siglo terrible. El aislamiento producido por la restricción en la Carrera de Indias les colocó al borde del suplicio. Así lo hacían saber en el propio año 1629 , por ejemplo, cuando se declaraban «sin ningún género de moneda» y viviendo «solamente de raíces y maíz» ${ }^{28}$. En 1625 un comerciante describía al lugar como un sitio en el que la gente no tenía ropa con la cual vestirse. Junto a ello, las epidemias mermaban la mano de obra, por lo que llegaron a solicitar «negros fiados» con el objeto de recobrar la productividad ${ }^{29}$. Los enfrentamientos con los indígenas resistentes, además, disminuían su capacidad de control de la región; hacia 1619, como una muestra del problema, hubo que resignar dos poblaciones a la aniquilación ante los ataques de los naturales ${ }^{30}$.

27. Sobre este sismo vino a saberse recién en 1999; véase: Grases, J.; Altez, R., y Lugo, M.: Catálogo de Sismos Sentidos o Destructores..., op. cit., p. 65. Hay estudio: Altez, Rogelio y Audemard, Franck: «El sismo de 1629 en Cumaná: Aportes para una nueva historia sísmica del oriente venezolano», Boletín Técnico IMME, Caracas, 46, N. . 2, (2008), pp. 53-71.

28. AGI, Contaduría, 1653, Cuentas de Real Hacienda y de obras para el fuerte de Araya, declaración de Gaspar de los Reyes Durán, Cumaná, 2 de marzo de 1630.

29. AGI, Santo Domingo 190, Expediente La Ciudad de Cumaná sobre que se le haga merced de ciertas cosas contenidas de su relación, Cumaná, 6 de marzo de 1602.

30. AGI, Santo Domingo 190, La Ciudad de Cumaná sobre que se le haga merced de ciertas cosas... Sobre la situación con los indigenas, 20 de diciembre de 1617; sobre el envío de hombres para la repoblar, 21 de febrero de 1619. 
La precaria infraestructura de la ciudad, lentamente desarrollada, describía su deficiencia material y con ello su carencia de recursos. El canal hacia el Puerto de Ostias y unas trincheras allí cavadas para su defensa, la clausura del cauce original, el fuerte de Santa Catalina y el de San Antonio de la Eminencia, eran las únicas construcciones levantadas en los setenta años que van desde la propuesta de Suárez de Amaya hasta la conclusión del último de esos fuertes. Si se toma en cuenta el tiempo desde su fundación, se trata entonces de unos cien años de tardanza en levantar estas construcciones. Desde luego, la atención al castillo de Araya será perentoria y excluyente en ese proceso, pero mientras tanto Cumaná no contaba ni siquiera con un puente con el cual vadear el río para cruzar a la otra orilla. Para contar con ese puente, la ciudad tendría que esperar hasta $1766^{31}$. Además, y como lo mencionamos antes, la batería de Santa Catalina apenas fue eficiente por una década, y del fuerte de San Antonio se decía en 1681 que era una «fábrica de barro» débil e incapaz, por lo que se estaban disponiendo a hacer uno nuevo en su lugar ${ }^{32}$.

A pesar de la atención a la fortificación de Araya, hacia 1680 su construcción daba cuenta de una grave ausencia de mantenimiento. Grietas en uno de sus baluartes, cuarteles descubiertos y arruinados, y un aljibe que acusaba «58 años que no se limpiaba», enseñaban que los tiempos de urgencias y correrías tras los holandeses ya habían pasado, y que los recursos de la región eran nulos ${ }^{33}$. La imponente obra de Antonelli era ya un peso excesivo para las condiciones materiales de Cumaná y de toda la Tierra Firme.

Cuatro eran las edificaciones religiosas de la ciudad hacia 1680: los conventos de Santo Domingo y San Francisco, la iglesia parroquial y la ermita del Carmen. Al otro lado del río se hallaban dos pueblos de indios, el de Nuestra Señora de Altagracia y el de Nuestra Señora del Socorro, separados por el cauce y entendidos como recintos diferentes al de la urbe. Cerca de 300 vecinos poblarían a Cumaná, lo que probablemente equivalía a unos 1.200 habitantes. Tal era la ciudad en esa época ${ }^{34}$.

31. Será construido en 1766 por el gobernador Pedro de Urrutia. Archivo Histórico Nacional, Madrid, Consejos Suprimidos, Libros de Matrícula, 3174, legajo 20570, Relación de los Servicios del Coronel don Pedro Joseph de Urrutia, Cavallero de la Orden de Santiago, Gobernador que ha sido de la Provincia de Cumaná y antes de Portovelo, Madrid, 16 de diciembre de 1776.

32. AGI, Santo Domingo, 595, Real cédula en respuesta a la situación de las fortalezas de Cumaná, Madrid, 31 de julio de 1682.

33. AGI, Santo Domingo, 584, Relación de don Juan de Padilla Guardiola, oidor de la Audiencia de Santo Domingo, destacado en Cumaná para verificar los excesos cometidos por su gobernador don Francisco de Vivero y Galindo, 9 de enero de 1682.

34. Estimamos la cifra a partir del informe hallado en AGI, Santo Domingo, 595, Joseph Ramírez de Arellano al rey, Cumaná, 18 de mayo de 1701, en el que se mencionan unos 350 vecinos para esa fecha. Entre las imágenes que corroboran el horizonte urbano de la ciudad, véase: AGI-MP, Venezuela, 72, Plano del pueblo de Nuestra Señora de Altagracia y del reparto de tierras a los indios del mismo, con vista de Cumaná y de la fortaleza de Araya, 1704. 
Sobre estas condiciones golpearía el terremoto del 4 de mayo de 1684. Todas las edificaciones religiosas se vieron maltratadas, mientras que la estructura antigua del fuerte de San Antonio de la Eminencia se demolió con el temblor. El de Santa María de la Cabeza «se rindió por cuatro partes», y todas las casas padecieron estrago. El fuerte de Santa Catalina, como sabemos, ya estaba en el suelo antes del sismo $^{35}$.

En la ciudad como en Araya hubo emanaciones sulfurosas, mientras que en el castillo que custodiaba la sal hubo daños de consideración. Todo el edificio se vio lastimado, así como sus almacenes, capilla y baluartes. El terremoto de 1684 fue un hecho diferente a los temblores anteriores. Halló una ciudad más desplegada, aunque significativamente vulnerable. Los daños, que en general abracaron todo cuanto representaba la infraestructura de la zona, indican la deficiencia material característica de un territorio sin riqueza mineral y desatendido por la metrópoli. Son daños que dan cuenta de una región marginal en las Indias.

Si el castillo de Araya fuese una escala comparativa del problema, vale la pena subrayar que todo el esfuerzo y la inversión en su construcción enseñaron una inmensa contradicción con las condiciones materiales de la región, y especialmente de Cumaná, la ciudad que debía mantener el fuerte. Ya en 1630 se denunciaba que no «puede haber ni del situado ni de sobras de él ni de esta hacienda ninguna de qué poder pagar» las deudas contraídas por el mantenimiento de la obra ${ }^{36}$. Aquel situado, también cargado a las cajas de Caracas, Cartagena, Panamá, Perú y México, podría tardar años en llegar, y mientras tanto se les pagaba a los soldados con maíz. Con todo, hasta el maíz escaseó, y la paga igualmente se atrasaba, como ya se denunciaba en 1686, cuando, además, se sacaban las cuentas de los daños causados por el sismo ${ }^{37}$. Hacia esta fecha, con unos ciento veinte años de fundada, Cumaná reflejaba la pobreza de la región y el lugar preciso en el que se regodeaba la periferia de las Indias.

35. Información sobre el terremoto en: AGI, Santo Domingo, 188, R. 2, N. 25, Francisco de Vivero Galindo al rey, Cumaná, 11 de julio de 1684; AGI, Santo Domingo, 188, R. 3, N. 33, Gaspar Mateo de Acosta al rey, Cumaná, 27 de noviembre de 1686; AGI, Santo Domingo, 190, cabildo de Cumaná al rey, Cumaná, 18 de diciembre de 1684.

36. AGI, Santo Domingo, 191, Cristóbal de Eguino al rey, Cumaná, 18 de junio de 1630.

37. AGI, Santo Domingo, 188, R. 3, N. 33, Gaspar Mateo de Acosta al rey, Cumaná, 27 de noviembre de 1686. 


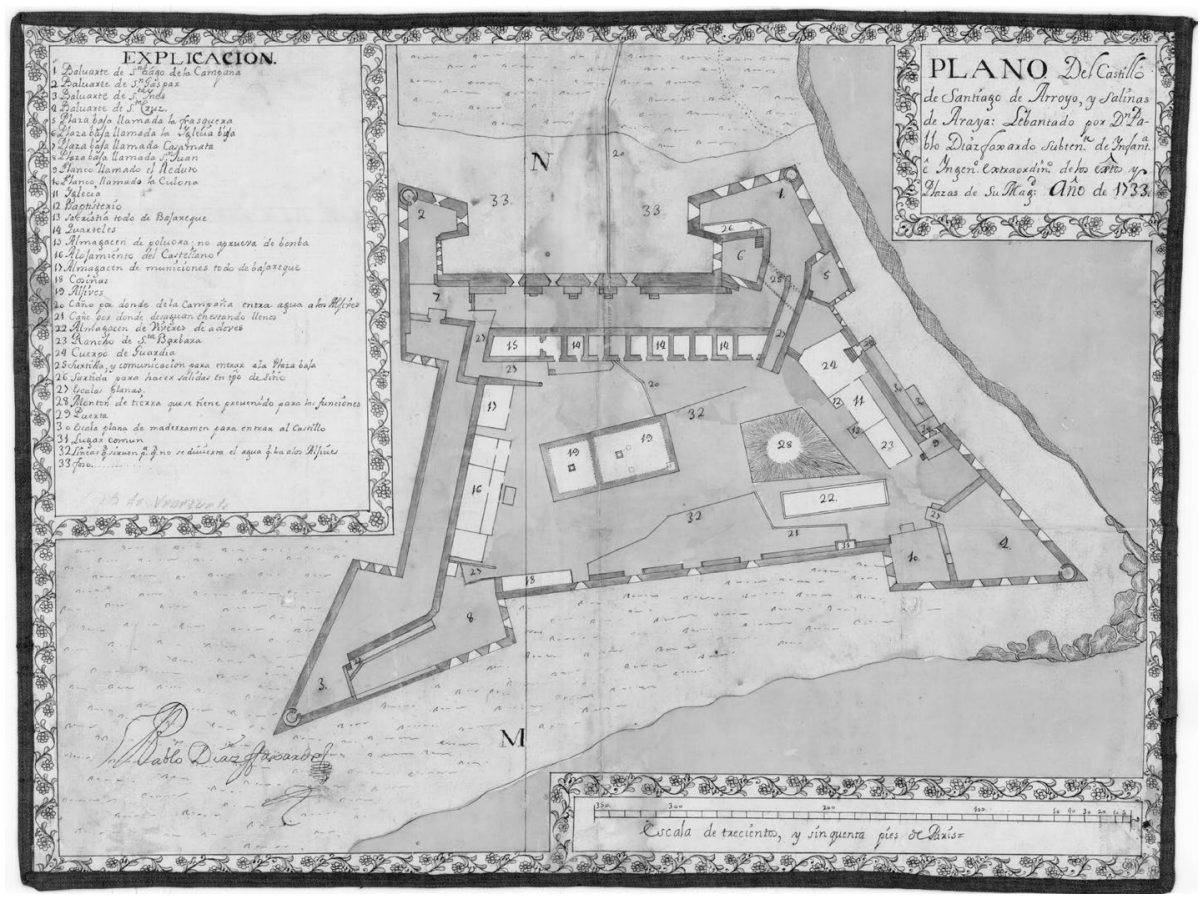

Figura 5. Plano del Castillo de Santiago de Arroyo y salinas de Araya, $1733^{38}$.

\section{LOS PEORES AÑOS}

Periférica, agrodependiente y precaria era la vida en Cumaná. La desatención por parte de la metrópoli, la ausencia de recursos y la carencia de medios para su mantenimiento fue un lamento común y sostenido desde sus inicios. La característica más emblemática de su existencia fue la materialidad deficitaria que le envolvía, corroborada una y otra vez durante décadas.

Sin riquezas, fragmentada regionalmente, y expuesta a una interminable lista de riesgos que pasaban de la condición de amenaza latente a la de realidad mortífera en pocos instantes, Cumaná y su zona de influencia manifestaron interminables situaciones deplorables. La pobreza era el rostro de su cotidianidad, y las solicitudes de mercedes y ayudas acabaron por ser la forma característica de comunicación con la Corona desde su fundación. Era el efecto sostenido de la ausencia de metales preciosos.

Ya golpeados por estas condiciones, tal como lo vimos, y en medio de las ruinas causadas por su propia deficiencia y por el terremoto de 1684, llegaron las langostas. Para el año 1702 se refieren estragos causados en la Provincia de Cumaná. Es

38. Servicio Geográfico del Ejército, A. ${ }^{\circ}-\mathrm{J}-\mathrm{T}-8-\mathrm{C} .{ }^{\mathrm{a}}-2 .^{\mathrm{a}}-\mathrm{n} .{ }^{\circ}$ 67, tomado de Cartografía y Relaciones Históricas de Ultramar, Tomo VI, Venezuela, Madrid, Ministerio de Defensa, 1990, N. ${ }^{\circ} 95$. 
probable que entraran desde Colombia por Trujillo y avanzaran por la región norte ${ }^{39}$, pues para finales del siglo XVII se reportaron destrucciones causadas por los insectos en aquella localidad andina, así como en Barquisimeto, El Tocuyo y Carora ${ }^{40}$. En 1706 ya informaban de unos cinco años de presencia de langostas en la Provincia de Caracas $^{41}$.

Esta invasión se produjo en un escenario de pobreza generalizada, no sólo en Cumaná sino en el resto de las regiones hoy venezolanas. Las plagas se unieron a las epidemias que venían afectando la población de la zona. Hacia 1701 a la estrechez económica se unieron la viruela y el vómito, afectando de manera particular a esclavos e indígenas. Igualmente, para los primeros meses de este año se habla del poco aprovechamiento de las tierras para la producción agrícola aunados a sus problemas de esterilidad. Los vecinos se hallaban endeudados y los campos sin cultivar ${ }^{42}$.

39. Aunque parezca poco probable que los insectos hayan sido capaces de volar la enorme distancia que media entre Cartago, ubicado en la región Andina de la Colombia actual, y Cumaná, emplazada en la región nor-oriental de la geografía hoy venezolana, no se debe subestimar el potencial reproductivo y migratorio de las langostas, cuya velocidad puede alcanzar 3.7 kilómetros por hora y una amplitud de vuelo de 35 kilómetros, además pueden conseguir una altura de 2.000 metros en su vuelo y recorrer hasta 2.000 kilómetros. Con respecto a sus características reproductivas, una ovipostura puede contener entre 40 y 150 huevecillos, entonces si la hembra de una pareja de langostas pone un promedio de 120 huevecillos, para que la población no aumente al año siguiente, 118 de ellos o de los insectos a que dan lugar, han de perecer antes de la puesta. Si en lugar de sólo dos langostas adultas, sobreviven 4, 6, 8, 10 ó 50, entonces el número de peregrinas al otro año habrá aumentado 2, 3, 4, 5 ó 25 veces, respectivamente. Véase: Metcalf, Clell L. y Fuint, Wesley P.: Insectos destructivos e insectos inútiles: sus costumbres y su control, México, Editorial Continental, 1981, p. 105 y 121; Domínguez García-TeJero, Francisco: Plagas y enfermedades de las plantas cultivadas, Madrid, Editorial Dossat, 1965, pp. 30-31, y 209; Bus Bus, Antonio: «Control de las plagas de langosta y modernización agrícola en la España de la segunda mitad del siglo XIX», Cuadernos críticos de geografia humana, Barcelona, № 95, (1992), pp. 4-18. Dentro de los conocimientos que se poseen del proceso migratorio de las langostas, Domínguez García-Tejero afirma que en fase gregaria marchan siempre en línea recta, atravesando cuanto se opone en su camino, sean ríos, montañas u otros elementos de carácter natural o humano. Asimismo, señala que cuando han adquirido la madurez y después de los apareamientos, pero antes de la puesta, realizan nuevos vuelos pero en dirección opuesta, efectuando el desove, para lo cual prefieren terrenos con escasa vegetación. Cómo se verá más adelante, durante este tiempo hubo escasez de lluvias en el oriente venezolano, lo cual soporta esta premisa.

40. En 1701 la ciudad de Cartago, actual Colombia, fue invadida por una plaga de langostas que migraron desde el sitio conocido como El Castigo perteneciente al Valle del Patía destruyendo las siembras y ocasionando una gran hambruna, por lo cual sus pobladores pidieron auxilios en alimentos a Santafé. Debido a los estragos causados por los insectos el rey Felipe II ordenó su destrucción en todos los territorios de dominio español, alarmado por los daños sobre la agricultura. Sobre su presencia en Cartago para la época, véase: Vélez Ocampo, Antonio Cartago, Pereira, Manizales: cruces de caminos históricos, Pereira, Editorial Papiro, 2005. Para mayores detalles de la información en las ciudades de Trujillo, Barquisimeto, Carora y El Tocuyo: AGI, Santo Domingo, 213, Información de los mulatos de Trujillo, 9 de enero de 1693.

41. AGI, Santo Domingo, 799, El Cabildo Eclesiástico de Caracas al rey, Caracas, 4 de diciembre de 1706. 42. AGI, Santo Domingo, 95, Joseph Ramírez de Arellano al rey, Cumaná, 18 de mayo de 1701. 
Hacia 1706, cuando Alberto de Bertodano asume la gobernación de Cumaná, llega el peor momento a causa de los daños producidos por las langostas ${ }^{43}$. Un par de años después, en 1708, se exponen las penurias que venían sufriendo por los insectos «que a cinco años permanece en estas tierras asolando los sembrados sin haberse podido lograr ninguna cosecha, costando mucho trabajo y afán el mantener la infantería de estos Castillos, y el Principal de la Real fuerza de Araya» ${ }^{44}$. El cabildo denunciaba «las más suma estrechez y necesidad en que la langosta y otros contratiempos han puesto esta Provincia, viéndose aniquilada, y sus vecinos y moradores destruidos por la falta y carestía de bastimentos y la precisión de irlos a buscar» ${ }^{45}$. Pero las langostas no llegaban sin su nefasto antecedente: las sequías ${ }^{46}$.

A fines del siglo XVII se reportaron «grandes secas» en la zona, que luego prolongaron sus efectos con la llegada de las plagas ${ }^{47}$. En los primeros años del siglo siguiente, la ausencia de precipitaciones se prolongó gravemente, sumando mayores dificultades en la región. En mayo de 1708 hubo que abastecer de emergencia a los soldados de Araya, trasladando agua desde el río Cumaná para su propia subsistencia, distante a tres leguas de travesía por $\operatorname{mar}^{48}$. En Cariaco la sequía y las langostas estuvieron acompañadas de gusanos que devoraban las siembras. Allá los habitantes se vieron en la necesidad de alimentarse con «raíces de palo y yerbas» para poder sobrevivir. Mucha gente murió a causa de ingestas nocivas ${ }^{49}$.

43. AGI, Santo Domingo, 612, El Cabildo, Justicia y Regimiento de la Ciudad de Cumaná da cuenta a Vuestra Majestad de la solicitud y desvelo con que el gobernador Alberto de Bertodano atiende las cosas del real servicio a Vuestra Majestad y al aumento y conservación de dicha ciudad, 7 de febrero de 1708.

44. Archivo General de la Nación, Caracas (AGN), Reales Cédulas, Sección Segunda, Tomo VIII, Al Gobernador y Oficiales de la Real Hacienda de la Ciudad de Caracas. Ordena enviar al Presidio de Cumaná los 10.000 ducados que tienen en cajas y remitan la relación de lo ordenado, Madrid, 16 de julio de 1707, f. 70.

45. AGI, Santo Domingo, 612, El Cabildo, Justicia y Regimiento de la Ciudad de Cumaná da cuenta a Vuestra Majestad..., 7 de febrero de 1708.

46. La aparición y propagación de las plagas de langostas presentan una relación de dependencia con respecto a épocas de escasez de precipitaciones. En este sentido, las consecuencias sobre la agricultura son doblemente negativas, pues destruyen las cosechas, ya de por sí escasas como consecuencia de la sequía, ocasionando hambruna e incluso mortandad. A su vez, los insectos en fase adulta se ven incentivados por las altas temperaturas. El calor activa la marcha, mientras que la puesta de huevos se realiza en terrenos incultos con poca vegetación, por lo que en este caso se ve favorecida también la reproducción gracias a la ausencia de lluvias. Véase: Domínguez García-Tejero, F.: Plagas y enfermedades..., op. cit; y también, Retana, Alberto José: «Relación entre algunos aspectos climatológicos y el desarrollo de la langosta Centroamérica Schistocerca piceifrons piceifrons en el Pacífico Norte de Costa Rica durante la fase cálida del fenómeno El Niño-Oscilación Sur (ENOS)», Tópicos Meterológicos y Oceanográficos, $\mathrm{N}^{\circ}$ 7, (200), pp. 73-87.

47. AGI, Santo Domingo, 188, R. 3, N. 33, Gaspar Mateo de Acosta al rey, Cumaná, 27 de noviembre de 1686.

48. AGI, Santo Domingo, 597, Repite la miseria a que esta reducida aquella Provincia por la plaga de langosta que padece desde el año 1707, 18 de agosto de 1708.

49. AGI, Santo Domingo, 597, Alberto de Bertodano al rey, Cumaná, 6 de agosto de 1709. 


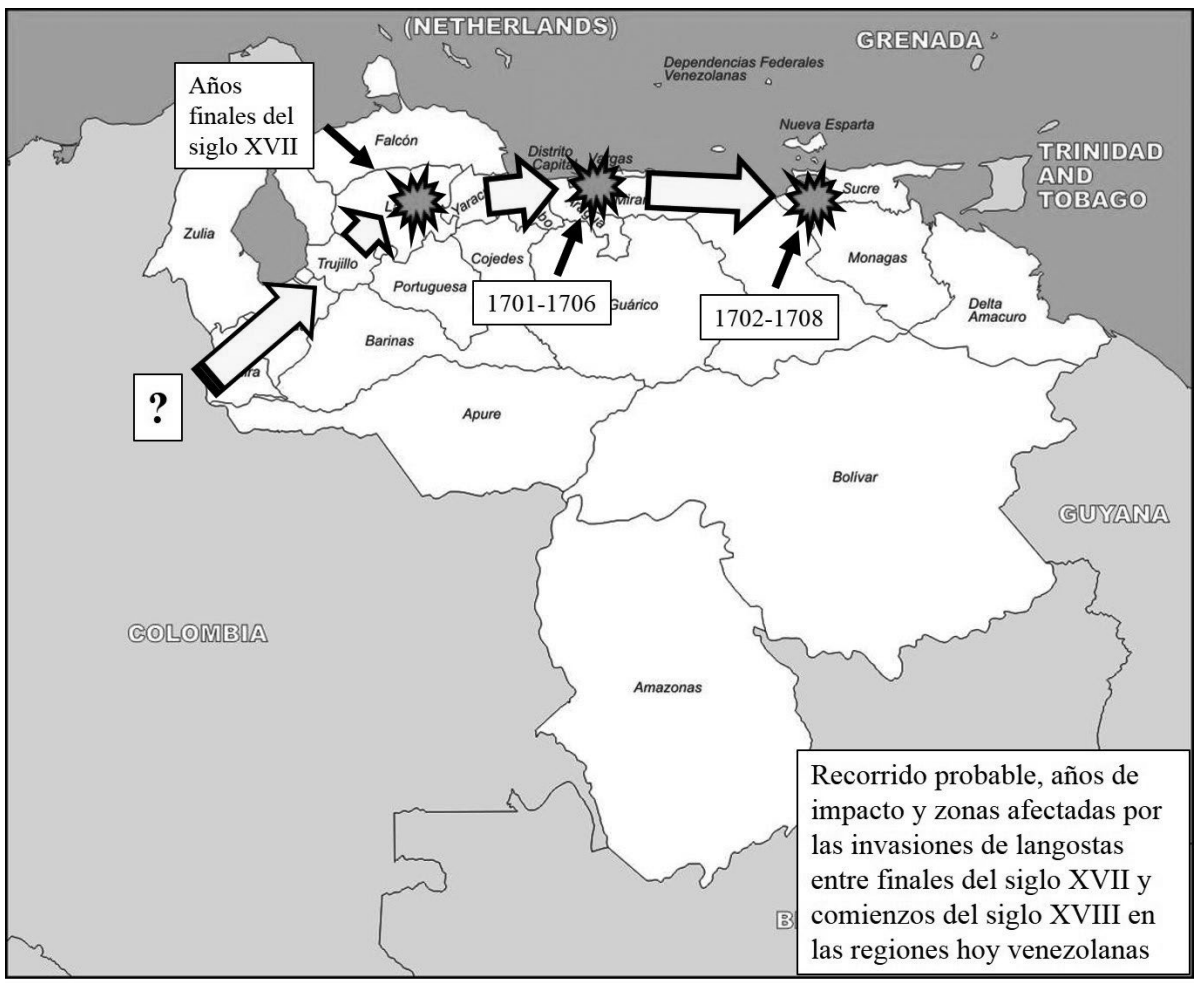

Figura 6. Ilustración que indica el impacto de la langosta en las regiones hoy venezolanas entre finales del siglo XVII y comienzos del siglo XVIII. Elaboración propia.

En 1709 continuaron los problemas de abastecimiento de agua para la guarnición de Araya como consecuencia de la falta de lluvias y la distancia que media entre el río y aquella localidad. Esta situación, sin duda común por la precariedad de las circunstancias generales, la tomó en cuenta otro gobernador, Joseph Francisco Carreño, quien destinó unas maderas para la elaboración de un pozo de veinte varas de circuito con el cual almacenar agua en el fuerte, material que fue aprovechado, también, para realizar reparaciones en la iglesia y un almacén para bastimentos. El pozo se pretendía construir «para ayudar a los aljibes, y que no tan a menudo padeciese la infantería con la falta de lluvias, los grandes costos que se hacen en la conducción de agua del río de esta ciudad a dicha real fuerza» ${ }^{50}$.

Sequías acompañadas de langostas y pérdidas de las cosechas producen quebrantos a corto y largo plazo. La magnitud de los daños puede ser tal que sus efectos se

50. AGN, Traslados, Colección Cumaná, Residencia del Gobernador Don Joseph Francisco Carreño, 1709, f. 51 . 
hagan sentir aún luego de haber transcurrido varios años, ocasionando devastaciones irremediables sobre las plantaciones, con la consecuente vulnerabilidad de la población ante la miseria y escasez de cultivos para el consumo, especialmente en sociedades agrodependientes y materialmente deficitarias ${ }^{51}$.

A los retrasos y largas faltas del situado con el que se pagaba a los soldados del castillo de Araya se sumaba el efecto de las langostas en las siembras, y especialmente en el maíz, la moneda por defecto que se utilizaba en la región. En 1706 informaba el gobernador que «la escasez de sustento y vestuario que padece aquel presidio, a causa de las cortas asistencias de su situado, y con tan inmenso trabajo el pan que se les da cada mes por correr a cargo de particulares, que a crédito del situado proveen los almacenes de granos, del que es mucha la falta en aquella provincia por la plaga de langosta, que ha cuatro años la aflige $»^{52}$.

Debido a las angustias del ejército, que abarcaba cien plazas entre los dos castillos de la ciudad, se ordenó que con la mayor puntualidad asistieran a la provincia con la consignación de los diez mil ducados correspondientes a sus arcas, advirtiendo que no admitirían disculpas algunas si se faltara a dicho mandato. Cinco años después, el situado aún no había sido recibido en la provincia, lo que motivó que se reiterara la orden de pago ${ }^{53}$. A pesar de la envergadura que suponía aquella fortificación y el inmenso despliegue de su mantenimiento (costes cargados a las cajas de Caracas y ciudades tan distantes como Cartagena, Panamá, Perú o México), los situados podían tardar años en llegar, evidenciando con ello la pérdida de interés en la obra y su inoperancia en aquella época.

Ya había sucedido algo similar en 1684, cuando el capitán general Diego de Melo Maldonado ordenó pagar los sueldos de la infantería de los castillos de la ciudad, pero los oficiales de hacienda se negaron por falta de fondos. Por entonces, y a reflejo del éxito del cacao en las provincias vecinas, en la región cumanesa se habían dedicado a sembrar el preciado fruto, pero no contaron con el mismo éxito de Caracas o Maracaibo: «con el poco valor que tiene el cacao, que como el único fruto que tiene

51. «Así pues lo verdaderamente catastrófico de todos estos males de carácter natural es que nunca se presentan de forma aislada. [...] unas malas cosechas continuadas, con sequías y plagas de langosta, pueden disminuir en bastantes años las posibilidades de recuperación de los cultivos». GARCía MorENO, Luisa: «El campesino hispano-visigodo entre bajos rendimientos y catástrofes naturales. Su incidencia demográfica», Antigüedad y Cristianismo, N. 3 (1986), pp. 180-181. Como lo mencionamos antes, Witold Kula fue quien llamó la atención, quizás por primera vez, sobre el problema de las «calamidades en la historia» producidas por lo que él denominó como «plagas elementales». Véase: KuLA, Witold: Problemas y métodos de la historia económica, op. cit.

52. AGN, Reales Cédulas, Sección Segunda, Tomo VIII, Al Gobernador y Oficiales de la Real Hacienda de la Ciudad de Caracas. Ordena enviar al Presidio de Cumaná los 10.000 ducados que tienen en cajas y remitan la relación de lo ordenado, Madrid, 16 de julio de 1707, f. 70.

53. AGN, Reales Cédulas, Sección Segunda, Tomo VIII, A los oficiales de la Real Hacienda de Caracas. Repite la orden de la puntual asistencia del situado en las cajas tienen los castillos de Cumaná, Zaragoza, 3 de febrero de 1711, f. 74 . 
esta provincia que la mantiene, y no haber quien lo pague de contado ni aun a diez pesos, es con extremo la necesidad de dinero que padece» ${ }^{54}$. En 1686 el gobernador Mateo de Acosta encontraría a los soldados de Araya sin maíz, ante lo cual debió pagar tres mil pesos de su bolsillo para comprar suministros ${ }^{55}$.

Para agosto de 1701 nuevamente se registran problemas para abastecer a los soldados de la región, ahora debido a la miseria causada por las langostas. En esta oportunidad el gobernador se vio en la necesidad de cambiar 67 cargas de cacao, pertenecientes a su propio salario, por maíz procedente de la Isla Española ${ }^{56}$. Solicitó a las misiones de Cumanagotos 700 fanegas de maíz, y antes de que dichos suministros se agotasen envió las 67 cargas de cacao, pero fueron robadas por un corsario inglés, colocándose en la penosa posición de solicitar 300 fanegas adicionales de maíz sin contar con los suministros que necesitaba para pagar la deuda hasta recibir el correspondiente situado procedente, en ese caso, de Nueva España ${ }^{57}$.

Tras seis años desde su aparición aún se apreciaban los efectos de la langosta sobre la cotidianidad cumanesa y el incremento de sus perjuicios por la ausencia de precipitaciones y la pobreza de la región. Las dificultades para abastecer las guarniciones, cargadas a los vecinos, apuraban aún más los aprietos para obtener los sustentos necesarios. Ante las solicitudes de colaboración por la guerra en Europa, el gobernador reconocía las dificultades que enfrentaba para recolectar las donaciones entre los vecinos. Entre todas las ciudades principales de la provincia no alcanzaron a reunir mil maravedíes ${ }^{58}$.

Será hasta el año siguiente cuando solicite el donativo correspondiente a la ciudad de Cumaná, esperando que las condiciones mejorasen. Reunió cincuenta pesos de su propio salario, más cuatro cargas y dos almudes de cacao. No obstante, reitera el gobernador la pobreza de los vecinos de la región y los aprietos que experimentó para la recolección, pues apenas había sumado 276 pesos y maravedíes reales en

54. AGN, Capitanía General-Diversos, Tomo I, Sobre que se paguen los sueldos a la infantería de los castillos de Cumaná, Caracas, 26 de febrero de 1684, ff. 156-157.

55. AGI, Santo Domingo, 188, R. 3., N. 33, Gaspar Mateo de Acosta al rey, Cumaná, 27 de noviembre de 1686.

56. Ya en el año 1686 se decía que por la inexistencia de moneda de cambio, se apelaba al trueque para subsistir, así por lo general se compraba maíz por cacao, cacao por miel y miel por carne. AGI, Santo Domingo, 188, R. 3, N. 32, Gaspar Mateo de Acosta al rey, Cumaná, 27 de noviembre de 1686, f. 2r.

57. AGI, Santo Domingo, 597, Repite la miseria a que esta reducida aquella Provincia por la plaga de langosta que padece desde el año 1707, 18 de agosto de 1708.

58. «...solo se pudieron juntar en la ciudad de la Nueva Barcelona trescientos y treinta y cinco reales y maravedíes de plata= en la de San Phelipe de Austrias cuatrocientos y veinte y cuatro reales= y en la de San Baltasar de los Arias los doscientos, y noventa y siete reales, por ser tanta pobreza, y calamidad que padecen las dicha ciudades especialmente desde el año de 1702 que entró en esta provincia la langosta, quebrando los deseos de servir a Vuestra Majestad». AGI, Santo Domingo, 597, Alberto de Bertodano da cuenta de los donativos de la región para la guerra, resaltando las dificultades de pobreza que viven sus vecinos y moradores, Cumaná, 1 de febrero de 1708. 
plata para entonces ${ }^{59}$. Además, en el propio 1709 se denunciaba que ya habían pasado cuatro años desde el último arribo de un navío al puerto de Cumaná, por lo que se hallaban necesitados de ropas, harina, aceite y vino, e incluso carecían de lo básico para celebrar la misa ${ }^{60}$. En aquellas circunstancias el donativo representó un esfuerzo significativo para la ciudad, aunado a los gastos de reparación de sus fuertes y del castillo de Araya, además de los constantes obstáculos que debían sortear para abastecer a los soldados.

No eran estos los únicos contratiempos por entonces. Las continuas inundaciones causadas por el río anegaban a Cumaná, por lo que en 1708, por ejemplo, ya se habían «perdido muchas casas» en la ciudad. El gobernador Bertodano solicitó personalmente el apoyo de los vecinos de la provincia a fin de reunir los recursos necesarios para abrir un nuevo canal por donde fluyera el río, «que duró hasta que cesó el invierno y las crecientes». El problema de las inundaciones contribuía, además, al deterioro de la iglesia parroquial. Su estado ruinoso preocupaba a los funcionarios de la región, pues tuvo que ser atendida con pago de limosnas a fin de evitar utilizar los caudales de la hacienda ${ }^{61}$. En 1701 ya se habían presentado dificultades con la crecida del río. En ese año dejó inhabitables algunas casas ${ }^{62}$. Esto reavivó la discusión sobre su anegación y sobre el canal de Santa Catalina. Una solicitud realizada por el entonces gobernador Ramírez de Arellano permitió que se continuaran las obras iniciadas por Gaspar Mateo de Acosta a fines del siglo XVII para regresar el caudal a su cauce original, obras que finalmente acabaría ejecutando Bertodano ${ }^{63}$.

Las condiciones bajo las cuales debían vivir, no sólo los ejércitos, sino además los moradores de la provincia eran lamentables, al punto de no contar siquiera con el apoyo eclesiástico necesario para sobrellevar, con la ayuda de la fe, las vicisitudes que permanentemente enfrentaban ${ }^{64}$. Una real cédula de 1706 describe las angustias

59. AGI, Santo Domingo, 597, Alberto de Bertodano da cuenta de los donativos de la ciudad de Cumaná para la guerra, 21 de enero de 1709.

60. AGI, Santo Domingo, 609, Alberto de Bertodano al rey, 30 de junio de 1709.

61. Antes del temblor de 1684 la iglesia ya se encontraba en mal estado; para su remodelación los vecinos donaron materiales de construcción pero debido a la negligencia de los curas, de acuerdo a Ramírez de Arellano, para 1701 se perdieron dichos materiales y hubo que iniciar la reconstrucción como mejor se pudo. Será con esta nueva colecta del gobernador Bertodano que se realicen otras intervenciones obre la edificación. Sin embargo, años después los vecinos se seguirán quejando de las condiciones de la iglesia. AGI, Santo Domingo, 595, Joseph Ramírez de Arellano al rey, Cumaná, 12 de junio de 1701.

62. AGI, Santo Domingo, 595, Joseph Ramírez de Arellano al rey, Cumaná, 20 de mayo de 1701.

63. Bertodano fue un gobernador muy activo y aparentemente eficiente. Además de estas intervenciones, orientó esfuerzos a reparar las trincheras de Cumaná que estaban afectadas por las inundaciones, terraplenó un barranco en el castillo de San Antonio, remodeló los cuarteles de Araya, desmontó las playas de acceso para evitar escondites a los enemigos y se encargó de la reedificación de la iglesia parroquial, «ocupando en estos trabajos a las milicias y vecinos de la ciudad». AGI, Santo Domingo, 597, Alberto de Bertodano al rey, Cumaná, 31 de enero de 1708.

64. En tiempos de calamidades, «estas sociedades agrarias, siempre desprevenidas cuando sucedía una catástrofe», hallaban soluciones afectivas a sus circunstancias en forma de plegaria, como lo dice Armando Alberola Romá. Véase del autor: «La natura desfermada: Al volant de manuscrits, impresos i imat- 
de los feligreses por no haber sido visitados por el obispo de la diócesis, así como las vicisitudes derivadas de la distancia que guardaban con la sede episcopal, hallada en Puerto Rico ${ }^{65}$.

A estas dificultades se sumó un evento sísmico ocurrido el 19 de julio de 1709 en la misma región oriental de la actual Venezuela, ocasionando daños sobre la estructura de la iglesia de la localidad de Cariaco. Necesitándose sólo mil pesos para su reparación, la solicitud de ayuda fue elevada a la Corona. Hasta cinco años tardó en llegar la respuesta de la metrópoli a la demanda de auxilio, cargando a Cumaná la responsabilidad de cubrir los gastos. Esto no se pudo cumplir por no contar con los caudales necesarios para el caso. Sumidos en la más profunda miseria, las reparaciones de la iglesia nunca se concretaron. Se ordenó su demolición en 1731. Tampoco hubo fondos para ello, y la iglesia se mantuvo en pie hasta 1738, cuando la consumió un incendio ${ }^{66}$.

En 1712 el Obispo de Puerto Rico, por fin, dispensó una visita al lugar. Su informe dio cuenta de un contexto que parecía inalterable desde los orígenes de su ocupación. Comentaba sobre «el miserable estado en que están los Pueblos de miserables Indios de esta Provincia», tal como si estuviese describiendo las mismas circunstancias habidas unos cien años antes ${ }^{67}$. Aún con la disponibilidad de los pobladores y la voluntad del gobernador Bertodano, las condiciones generales de Cumaná no mejoraron. La falta de recursos dificultaba el mantenimiento y abastecimiento de los soldados, la agricultura sufría los embates de las sequías y las plagas, y la población se sumía en la más absoluta desgracia acompañada de epidemias y eventos telúricos, aunado a las constantes inundaciones del río, acecho de enemigos y pobreza generalizada ${ }^{68}$.

ges sobre desastres naturals en l'Espagna del segle XVIII», en Alberola RomÁ, Armando y OlcinA CANTOS, Jorge, Editores, Desastre natural, vida cotidiana y regligiosidad popular en la España moderna y contemporánea, Alicante, Universidad de Alicante, (2009), p. 20.

65. «Mi Gobernador y Capitán General de la Ciudad de Santiago de León de Caracas, hallándome informado por persona de particular celo de mi mayor servicio que de muchos años a esta parte no se han visitado por el obispo de Puerto Rico la Provincia de Cumaná y la Isla de Margarita que son de la diócesis de aquel obispado. Es grave desconsuelo de los moradores de una y otra parte, y que mueren en ella mucha personas sin conseguir el sacramento de la confirmación; aunque se añade que para recibir órdenes y dispensas en matrimonios ha sido preciso hacer viaje a Puerto Rico con riesgo de las vidas de los pretendientes en los peligros de la navegación por lo dilatado de ella, por los riesgos de enemigos, y por la poca seguridad de la calidad de las embarcaciones y que algunos que han conseguido llegar a salvamento a Puerto Rico han fallecido en aquella isla por no haberse hallado embarcaciones en que restituirse a sus Patrias». AGN, Reales Cédulas, Tomo VI, Al gobernador y capitán general de la ciudad de Santiago de León de Caracas sobre la ausencia del obispo de Puerto Rico en Cumaná y la Isla de Margarita, Caracas, 21 de abril de 1706, f. 12.

66. AGI, Santo Domingo, 597, Alberto de Bertodano al rey, Cumaná, 6 de agosto de 1709; AGI, Santo Domingo, 589, real cédula, Madrid, 9 de noviembre de 1714.

67. AGI, Santo Domingo, 609, El visitador del obispado al rey, Barcelona, 25 de julio de 1712.

68. A pesar de todas estas condiciones adversas y de su sostenimiento en el tiempo, no se han hallado situaciones de protestas o demandas airadas por parte de la población ante las autoridades locales, ni mucho menos ante las metropolitanas. A diferencia de lo sucedido en Valencia (España), por ejemplo, durante 


\section{CUMANÁ, UNA POBREZA ENDÉMICA}

Podemos asegurar que los años que corrieron entre el sismo de 1684 y la primera década del siglo XVIII constituyen una coyuntura desastrosa en toda la región. Sin embargo, vistas sus condiciones desde los momentos fundacionales, tal parece que este periodo fue de los peores dentro de unas circunstancias que nunca cambiaron, y que aparentemente no han de variar mucho en adelante.

El siglo XVIII no habría de representar grandes avances para Cumaná y su región. Quizás el asentamiento de una mano de obra más controlada, producto de las avanzadas misionales que tuvieron lugar, precisamente, entre finales del siglo XVII y comienzos del XVIII, le otorgó mayores seguridades en la producción agrícola; pero en realidad la producción de las misiones nunca redituó en el desarrollo general del territorio, y todavía a finales de ese siglo se reportaban penurias y miserias en los propios recintos misioneros ${ }^{69}$. Las décadas finales de esa centuria, además, vendrían acompañadas por una secuencia de terremotos destructores de envergadura, con los cuales, para mayores desgracias, las edificaciones habrían de sufrir daños que arrastrarían por muchos años después ${ }^{70}$.

Los tiempos finales del modelo colonial, años en que el desgaste de su eficacia fue en aumento, enseñaron en Cumaná problemas similares a los que muchos funcionarios y autoridades venían denunciando doscientos años antes. Contrabando, falta de tierras labradas, un comercio extenuado, pobreza generalizada, y ahora más que nunca la proximidad de los enemigos, cuya amenaza sería una certeza inevitable en varias oportunidades, como cuando tomaron a Trinidad de una vez y para siempre ${ }^{71}$.

Lo que puede comprenderse sobre las circunstancias y características de Cumaná a finales del modelo colonial, debe leerse como una contundente expresión del proceso

el siglo XVIII, cuando por un «encadenamiento de malas cosechas», a decir de Alberola, se produjo un alza generalizada en los precios de los productos de primera necesidad, y por ello se desataron protestas populares que eventualmente alcanzaron la violencia, en estas regiones no hubo tales malestares. Véase: Alberola Romá, Armando: «Adversidades meteorológicas y protesta popular: Una aproximación a los problemas del campo valenciano durante el siglo XVIII», en Franch BENAVENT, Ricardo (Editor): $L a$ sociedad valenciana tras la abolición de los fueros, Valencia, Institución Alfonso El Magnánimo (2008), pp. 193-214. Quizás en esto, como en todo, operó igualmente la periferia y la inmensa distancia en la que se encontraban estas regiones, generando con ello un evidente debilitamiento de oportunidades de manifestación directa de sus incomodidades, o bien la desaparición de la consideración al respecto. En ello hallamos, al parecer, parte de la eficacia simbólica del modelo colonial, la que se sostuvo hasta su desgaste y colapso final, cuando por fin las discrepancias y los desacuerdos de intereses entre las Indias y la metrópoli reventaron en el proceso de las independencias hispanoamericanas.

69. AGI, Caracas, 275, Relación del estado de las doctrinas y misiones al cargo de los capuchinos aragoneses en esta provincia de Cumaná, Fray Silvestre de Zaragoza, Caripe, 17 de enero de 1771.

70. Entre los temblores que mayores daños causaron, pueden referirse los ocurridos en 1766, 1797, 1799 y 1802. Hubo otros menores, además, sin daños o bien convertidos en percutores de las ruinas causadas por los sismos mayores. Véase: Grases, J.; Altez, R., y Lugo, M.: Catálogo de Sismos Sentidos o Destructores..., op. cit.

71. Véase la relación que hace de todo ello el entonces gobernador de la provincia, Vicente Emparan, en AGI, Caracas, 132, Emparan al Ministro de Gracia, Justicia y Materias Eclesiásticas, 15 de febrero de 1799. 
histórico que le determinó desde su fundación: ausencia de riquezas minerales, agrodependencia ineficiente, materialidad deficitaria, y una indefectible vulnerabilidad que condicionó desfavorablemente su relación con el medio ambiente y con todas las amenazas naturales o antrópicas con las que convivió, conduciendo a resultados adversos cada una de las oportunidades en que éstas se cruzaron con aquel contexto.

Tal vulnerabilidad, ya estructural a la vuelta de más de dos siglos, también es la cristalización de la periferia a la que fue enviada por el desinterés de la Corona. Esta periferia, que compartió igualmente con sus provincias vecinas, produjo resultados diferenciales entre ellas, favoreciendo definitivamente a Caracas por encima de los territorios que le rodeaban, ya por tratarse de la ciudad que cobijaba a las élites más poderosas, o bien por haber superado a las demás en la competencia por la atención de la metrópoli. Todo puede comprenderse al aproximarse a este proceso desde una perspectiva de larga duración, pues con ello es posible advertir la conformación de aquellas condiciones, así como su reproducción en el tiempo.

No fue Cumaná el único asentamiento español en América con estas circunstancias. Tampoco fue la única ciudad ubicada en la periferia de las Indias. Sus vicisitudes no la empujaron al traslado, como sí ocurrió con otras poblaciones, pero la sometieron al padecimiento característico que sus condiciones le impusieron. El caso de Veracruz, por ejemplo, puerto como Cumaná y enfrentado a un medio ambiente hostil a la vida humana, tendrá como destino una discutida mudanza con resultados que no representaron un favorecimiento notable, aunque su destino como enclave comercial beneficiará su futuro. Su enclave original, sintetizado por Chaunu como «algo frágil y somero», trocará en «la ciudad de los muertos», como la llamó Elisée Reclus, un sitio «que todavía hoy... sigue siendo afectado por las enfermedades infecciosas $\rangle^{72}$.

La naturaleza como barrera o constricción al desarrollo de una ciudad fue una característica común a los asentamientos españoles en Indias. El trabajo de Musset da cuenta de ello, y su descripción de las «ciudades frágiles», con ejemplos demostrativos de las sucesivas y frecuentes mudanzas en muchos casos, expone circunstancias que coinciden con la situación de Cumaná. Dentro de las múltiples causas que empujaron a los pueblos a trasladarse, quizás todas revisadas por Musset, los sismos, la insalubridad, las inundaciones, las tempestades, las invasiones, la resistencia indígena, las

72. La descripción que hace Chaunu de la primera Veracruz, la fundada por Hernán Cortés, es elocuente: «Sol, dunas y pantanos... La ciudad padece calor, humedad, fiebres [...] no reúne tampoco las ventajas de un puerto bien emplazado. La barra del río, la arena, los vientos, demasiados peligros para los tesoros y las mercancías. Los navíos fondeados, frecuentemente, en San Juan, no se aventuran a ir allí. Abierta, sin protección, desde el punto de vista técnico, ha progresado poco desde su fundación. Las mediocres construcciones portuarias, las precarias obras de defensa, de cal, o de piedra traída de los islotes vecinos o venida de Campeche... no le conciernen. En la parte habitada, una ciudad de madera, de adobe, de paja. Las casas están construidas con la madera de desecho o de los navíos 'al través', aquellos, numerosos todos los años, que terminan sus vidas en las Indias. [...] todo falta, incluso el agua que se trae en grandes vasijas desde una laguna vecina de agua estancada» (Chaunu, P., Sevilla y América, op. cit., p. 111). La referencia a Reclus y la cita sobre la insalubridad de Veracruz en Alain Musset, Ciudades nómadas, op. cit., p. 124. 
plagas, los sitios con suelos deleznables, coinciden con nuestro caso; no obstante, aquí la ciudad resistió en el mismo lugar, aunque difícilmente podemos asegurar que tal resistencia representó su adaptación o robustez.

La exposición de esta sociedad a los embates de amenazas de todo tipo derivó en desastres de largas consecuencias. O bien, quizás podría asegurarse que la vida en Cumaná durante esta época fue una constante exposición a las adversidades. Desde luego, las amenazas no son la representación de una relación insoslayable entre «víctimas débiles» y «castigos incontrolables», sino la cristalización de una relación histórica-social-material-simbólica entre un contexto vulnerable (que transforma en amenaza a ciertas variables ante las que no tiene respuestas eficientes), y esas variables que no necesariamente producen los mismos resultados en todos lados.

Aunque poco o nada podría hacerse por entonces ante las langostas, por ejemplo, resulta pertinente subrayar que su impacto ha de ser directamente proporcional a las condiciones de vulnerabilidad del contexto donde golpean. La agrodependencia de las sociedades pre-industriales no fue una condición homóloga ni homogénea, sino diferencial y heterogénea, determinada por la ausencia o presencia de alternativas económicas y materiales ante la presencia de adversidades por el estilo. A decir de Witold Kula, se trata de fenómenos de la naturaleza que en otras circunstancias no hubieran representado ninguna calamidad, o bien, tales condiciones de vulnerabilidad en aquella sociedad prolongaron exponencialmente los efectos de las calamidades.

Está claro que la condición de sociedad pre-industrial no es invariablemente conducente a la agrodependencia, y que tal situación, además, no siempre produce sociedades deficitarias. En este caso, la región oriental de la actual Venezuela, representada por la ciudad que capitalizaba los intereses que la administraban y explotaban durante el modelo colonial, manifestó unas condiciones materiales y sociales que se correspondían con una agrodependencia resultante de un territorio sin riquezas atractivas a los ojos del centro de poder que produjo tal condición histórica. Su periferia, como su vulnerabilidad, son resultados históricos, productos concretos de un proceso que conformó esas condiciones. Las vulnerabilidades, por consiguiente, allí y en todo momento, no son fragilidades proporcionales al tamaño y calidad de las amenazas, sino estructuras históricamente producidas.

Por todo ello, Cumaná y su región vivieron sumergidos en una pobreza endémica sin remedio a través de aquellos interminables siglos de padecimientos continuos. Fue la expresión más conspicua de lo que Chaunu advirtió como los parientes pobres de Tierra Firme ${ }^{73}$, una condición que, probablemente, mucho tendrá que ver con su destino posterior, el de una periferia anclada ahora en un orden republicano que acabará reproduciendo, a su vez, las estructuras más profundas de sus orígenes, tan despreciados como denostados e incomprendidos por el discurso nacionalista y la historiografía tradicional, que poco se ocupan de enfocar su interpretación de la historia como una unidad indivisible.

73. Chaunu, P.: Sevilla y América, op. cit., p. 101. 